\title{
Salutary Meanings of Sublimation. Selected Soteriological Threads of Alienation Criticism of Religion ${ }^{1}$
}

\section{Jowita Guja}

\begin{abstract}
AGH University of Science and Technology in Cracow, Poland
\end{abstract}

e-mail: jowitaguja@poczta.fm

\begin{abstract}
:
The article concerns a few soteriological threads of alienation criticism of religion whose feature is the creation of a new autonomous and transgressive subject. It focused on the presentation of this subject using Nietzsche's philosophy perceived within Freudian perspective.

Keywords: atheism, soteriology, alienation, sublimation, repression.
\end{abstract}

\section{Introduction}

Speaking about soteriology in the area of atheistic philosophy may seem disputable as a term "salvation" is typically reserved for religious traditions. Contrary to this trend, I am proposing a thesis that salvation of a man can have a completely secular meaning. Literally, it can be understood as liberation from a negative state or negative circumstances. That is the comprehension found within the Old Testament and in the Judaic tradition. In Christianity, in turn, salvation has several meanings, out of which restoration of lost inner oneness or completeness to a human being seems to be the most important. We deal with such a perception of salvation in, among others, the Letter to the Romans by St. Paul, within which a split of man into an old (outer) one and a new (inner) one is mentioned and discussed; the cleavage that is to be overcome in Christ. In atheistic philosophy, one can come across a certain analogy to both of these senses while simultaneous reversing the religious belief itself. On the one hand, there is a Promethean theme in it with its matter of liberation from a certain negative state: a specific sin of culture - in this case, the sin is equal to a projection of God and to negative consequences of this activity. On the other hand, some atheistic trends tell of a crack in a man that is to be filled. This is precisely the purpose of alienation criticism of religion. However, the cause of the break in a man is accounted for a mechanism of religious alienation. The secular salvation is, in this case, consists in the restoration of man's lost unity and their introduction into a path of authentic existence, which they are devoid of in religion.

Depending on an atheistic trend with which we are dealing, numerous soteriological threads may be mentioned. All consistent plots of thought are characterized by Prometheanism associated with an idea of liberation by the truth. Besides, there may occur themes such as salvation through a 
close to mystical experience of a miracle of existence or an aesthetic experience (which is characteristic for New Atheism, for example of Richard Dawkins's or Sam Harris's), salvation by action, transformation of social reality and liberation from suffering (noticeable, among other things, in Russian philosophy, for example in Vissarion Belinsky's thought or in revolutionary atheism) and finally salvation by creation of a new subject. The last thread itself is precisely the main topic of this article. It is one of the factors determining peculiarity of alienation criticism of religion, whose soteriology focuses mostly on trying to create a certain existential, authentic and transgressive ideal. At the same time, the authentic existence constitutes the opposite of the existence that has been alienated by religious projection.

\section{Alienation Criticism of Religion - Description}

Alienation criticism of religion represented among other things by Ludwig Feuerbach, Karl Marx, Friedrich Nietzsche, Sigmund Freud, Jean-Paul Sartre or Slavoj Žižek is an extremely strong standpoint in a discourse opposing to religion. All its arguments focus on indicating the effects of a projection of an idea of God within the constitution of human subjectivity. It is symptomatic that it does not enter into discussions with any proof of God's existence, there is no place here for this kind of polemics with supporters of a theological hypothesis. As opposed to New Atheism, represented among for example by Richard Dawkins or Daniel Dennett, it also rarely focuses on such aspects of religion as the generation of political conflicts. For alienation criticism of religion, the consequence of God projection for human subjectivity and how this projection influences it is much more important. Social phenomena related to religion are rather depicted as a result of the alienation of subjects that create culture.

The name "alienation trend" which I have adopted, indicates the fact that an idea linking all its representatives is a concept of subject alienation - a belief that through religion a man simply cuts off from a certain valuable part of their own being, objectifies it and treats it as a strange one. This problem seems to be paradigmatically articulated in Feuerbach's words: 'Religion is a relation of a man to their own essence. Its truth and healing moral force are found within this relation. However, religion is the relation to the essence treated not as its own but as the other own, not only different but even opposite' [2, pp. 334-335] Feuerbach is recognized as a father of modern atheism, and he is often given credit for introducing a scheme of religious alienation: a man projects his best qualities in the other world, cuts off them, and finally pays homage to them. This activity results in a false self-image: a cult of God's projection involves humiliation of a human being. In fact, a concept of alienation within various shades of meaning - from a totally secular one in a sense of alienation of a man from neighbors or social institutions, through metaphysical alienation of a Spirit that is performing its own self-objectivization to alienation in an entirely religious sense which was described in a chapter of Phenomenology of Spirit concerning unhappy consciousness gained significance in Hegel's thought. He writes about it using both: a notion Entäusserung to mark the life of the Spirit that externalizes itself objectifying itself in nature and culture, and a notion Entfremdung to mark unhappy consciousness which is usually identified with the JudeoChristian consciousness. Feuerbach almost literally borrows the last term from him. It is indisputable it was him who popularized the notion within atheistic philosophy influencing consecutive critics of religion who then repeatedly followed a schema of alienation, modifying its meaning a bit each time. We find it in Marx's thought in an almost identical form and in a similar form in writings of Nietzsche who uses a term entfremdete Geist as well as he talks about alteration that takes place within religion. Freud and Žižek put the notion into words of psychiatry and psychoanalysis, Sartre speaks of an alienating, perverse, divine look. The ambiguity of the term "alienation" is also worth mentioning. It is used in numerous contexts within the topic discussed: beyond a classical Feuerbach meaning, one can notice among other things alienation of resentment subject (Nietzsche) that does not recognize actual reasons of their behavior and perception or 
cynical subject (Žižek) alienated by declarations and rituals that are accompanied by a frivolous and reserved attitude. The common denominator of these concepts is understanding of alienation of a subject as a situation within which the subject does not recognize certain aspects of their own existence as actually their own or it perceives their false image, thereby remaining in an inauthentic attitude.

The alienation criticism of religion owes to Hegel a lot more than just defining a key argument against religion. At the same time Hegelian phenomenology is a starting point and a counterpoint of an original perspective of study of human subjectivity - the archaeological perspective. The essence of this perspective is very well outlined by Paul Ricoeur's essay Freud and Philosophy: An Essay on Interpretation. This French thinker analyzes a thought of one of the representatives of alienated criticism of religion, Sigmund Freud. He treats it as a kind of hermeneutics exploring a key idea of the psychoanalyst in question: the subject is not what in fact they are. In other words, the point of view of consciousness is usually a false point of view. To achieve the truth of the subject, we must adopt a perspective of reductive hermeneutics, demystifying, reaching deep into the self-unconscious subject, in their arche. To all appearances, it seems that this hermeneutics is exactly the inverse of Hegelian phenomenology, which performs a reverse movement - it is not interested in the arche of the subject, but in their telos. While Freudism goes deep into the subject looking for the sources of meaning within the unconsciousness, in Hegel's phenomenology we deal with a forward movement towards an assumptive goal that is a full spirit. According to Ricoeur, we do not just have to do just with a reverse but with a shift: Freudian metapsychology, like Hegel's Phenomenology but in an opposite direction, carries out a shift of the centers of meanings, the birth of sense. However, despite this shift, Freudian psychoanalysis can be read in Hegelian perspective and thus it can reveal mutual points of Freud and Hegel's thought. The first of these points is the arche of the subject, which contrary to appearances, is perceived similarly by both thinkers.

Both Freud and Hegel are convinced that conscious subjectivity (together with culture) is born in the desire movement, which on the one hand can be noticed in a Freudian drama of the subject struggling with their own desire, and on the other can be seen in a Hegelian struggle for recognition. In Ricoeur's opinion, this struggle, which is about forcing another to confess that "I am an autonomous consciousness" means that the desire is transferred to a sphere of spirit: concepts of domination and surrender, which belong to a Hegelian language, denote the fate of drives in a Freudian language [32]. This similarity is sharpened by Kojève's direct interpretation of Hegel's struggle for recognition as a struggle between two opposing desires. Secondly, despite the fact that Freud's psychoanalysis emphasizes a role of archeology of the subject, there is also telos present within it. The concept remains very close to Hegel's assumptions - an ultimate goal of psychoanalysis is to broaden the consciousness of the subject. An ideal end of psychoanalysis is equal to the creation of the subject that is not alienated, and within which, there is a stable selfconscious self at the center.

Achieving this point, as Ricoeur points out, is reminiscent of the Hegelian phenomenology, with its phase of the struggle for recognition when we look at a process of raising the subject's consciousness in analytical relation. The process of self-awareness goes through the consciousness of another, an analyst's consciousness, what contains an element similar to a Hegelian struggle of two self-knowledges. Nevertheless, one cannot forget about differences: in Hegel's thought, we do not just deal with the phenomenology of consciousness, but with the phenomenology of spirit. As Ricoeur writes, the genesis of meaning does not originate in consciousness, but the consciousness itself is rather inhabited by a certain sense. The Spirit is a dialectic of definite figures (a master and a slave, stoic withdrawal, indifference of skepticism, unhappy consciousness, menial consciousness, etc.). The consciousness is an internalization of movement, which is also explored in structures of objective institutions, monuments, works of art, culture. Each figure gets its meaning from the one that follows it. Self-overcoming of the spirit creates the truth of the earlier figures that do not know 
about themselves without it. Hence the terminology - phenomenology of the spirit and not of the consciousness. Freud, in contrast to Hegel, is characterized by extreme skepticism about mechanisms of human consciousness. It is why Ricoeur calls him "a master of suspicion," the term which he shares with Marx and Nietzsche.

The focus on an analysis of the unconscious arche of the subject and the telos which is about withdrawing alienation and disenchanting of false consciousness, is a characteristic feature of a whole alienation trend. Feuerbach, Marx, Nietzsche, Freud and their contemporary heirs, joining in a specific way Hegelian tradition, at the same time oppose to the well-grounded understanding of a human subject in philosophy as a self-evident, stable, self-conscious cogito. A conscious subject ceases to be trustworthy for them, hence the inclination to enter deeply into arche of a subject that characterizes each of them. The source of subjectivity is not located in the open (conscious), but in the hidden. Freud talks about unconscious complexes and drives, Nietzsche mentions will to power and resentment that is to wear various masks. Marx notices the importance of power relations and economic forces in the genesis of consciousness constructs, such as religion, art or philosophy. In all these cases, what is hidden becomes building material of that what is open, at the same time escaping from the domination of the subject. Resentment produces values, economic power creates ideology, anxiety and wishful thinking originate religion. Drives are expressed in sublimation, erroneous activities, neurosis and dreams. At the same time, alienated critics of religion clearly outline the telos, that is broadening of the field of consciousness and achieving the widest possible range of self-control. The attitude to religion presented by the discussed thinkers does involve such understanding of the subject.

\section{Religion as a Dream of a Human Spirit}

Understanding of religion in alienation criticism is already reflected in the language of its representatives. Let's have a look at some definitions of religion that can be found in their works. According to Feuerbach, religion is "a dream of a human spirit", according to Marx it is "opium of the people", "imaginary happiness." Nietzsche speaks of "omma", Freud of "obsessive compulsive disorder" and "a sleeping-pill." Finally, for Žižek, religion is involved in "phantasms" underlying social reality. Comparisons to sleep, mental illness or narcotic illusion prove that religious beliefs cannot be reduced to a simple cognitive error and their genesis is more complicated. The concept of religion as a dream seems to be the most paradigmatic of all these definitions. It seems to achieve its full meaning when one reflects at it from a Freudian perspective where religion has a clearly similar structure to dreams. Although in Freudian psychoanalysis a definition of religion as "collective neurosis" has become much more popular, here we do emphasize an analogy of religion and a dream as it has a much broader scope and is used by almost all representatives of alienation criticism of religion.

Already at the beginning of Interpretation of Dreams Freud categorizes a dream within the same sequence of "abnormal mental formations" that includes diseases such as a hysterical phobia or insane and obsessive dreaming [4, p. XXIII]. A diagnosis of religion as an obsessive compulsive disorder by its structure is in line with the same group of the formation. The analogy between dreams and religious beliefs is later confirmed by Freud in Totem and Taboo [7]. Interpretation of Dreams, Freud's first larger work from 1900, makes a supported by numerous examples study into explaining etiology of dreams based on a complex number of causes, displaced complexes and camouflaged wishes. It suits perfectly the outlined concept of the subject who is not the master themselves.

Distinctive features of a dream and a neurosis (including a religion, that is a collective neurosis) are as follows:

1. They hide their true motivation. They can cover it with another, quite consistent system. We always have to do with a kind of facade that is accessible to our consciousness, the one which at the 
same time hides its true determinants. In a case of a dream this façade is created by the content of a dream story, whereas the hidden part consists of dream thoughts (a coherent complex of suppressed wishes that are expressed within the dream content but in a strongly camouflaged way). Work of a dream transforming hidden dream thoughts into a content of a dream that becomes accessible to consciousness is very complicated and uses a variety of mechanisms, such as condensation or dislocation. Similarly to a case of neurosis - its symptoms show coherence and consistency, but this consistency is apparent, because in reality the symptoms take their vitality out of the determinants that are hidden. This procedure also applies to a Freudian collective neurosis, that is religion.

2. They are not irrational - according to Freud, every dream, in reality, is a sensible psychic creature that should be placed in a locally identifiable mental state of vigilance. In other words, there is a close connection between a dream (neurosis/religion) and the reality that is known to a subject. Symptoms result from real events that take place in the subject's mental life and they express them. As long as we agree that religion in alienation criticism of religion has a similar structure as a dream in Freud's classic psychoanalysis, we must admit that it does not have much in common with a simple mistake of irrational thinking. Its ground is as real as possible. Ludwig Feuerbach does recognize this aspect of religion while writing: 'Religion is a dream of a human spirit. But also in a dream, we are not in nothingness or in heaven, but on earth, in a kingdom of reality, with a one and only difference that we see real objects not in the light of reality and necessity, but in a fantasy world of delusion and randomness' [2]. Certainly such a depiction of religion will stay in line with Karl Marx's view who looks for its etiology in the most tangible of factors - the "opium" does not come from nowhere, it is 'an expression of real poverty/misery and at the same time a protest against real poverty/misery' [19]. In spite of an illusory form that religion adopts its genesis is rationally explained by economic conditions. However, these determinants are not recognized by the subject.

3. The explanation of dreams and hence the criticism of religion which remains characteristic for alienation trend, in its basic design is a decryption that is intended to lead to broadening of consciousness and the subject's recovery of themselves.

4. A dream and all forms of mental life whose structure is similar to it contain both the truth and the untruth, or rather the truth in a form of illusion. Despite a strong camouflage using apparent irrationality, a dream contains a hidden truth about human nature in a pictorial form: 'Thus dreams would reveal the true nature of man, though not his whole nature, and they would constitute one means of rendering the hidden interior of the mind accessible to our knowledge' [3]. The truth about this interior very often does not have building character. Let's recall another passage from a Freud's work: 'In this, psycho-analysis is no more than confirming the habitual pronouncement of the pious: we are all miserable sinners' [5, p. 48].

Remembering the concept of religion as a dream, let's illustrate it with an example of Nietzsche's thought. In The Daybreak one can find two very important quotations. The first one is as follows: 'Awaking from a dream. Noble and wise men once upon a time believed in the music of the spheres; there are still noble and wise men who believe in "the moral significance of existence," but there will come a day when this music of the spheres also will no longer be audible to them. They will awake and perceive that their ears have been dreaming' [20].

"For Nietzsche" the moral sense of existence" and religion are bilaterally related. On the one hand, the predominant moral system in a particular society is designated by religious outlook. On the other hand, the religion is founded on morality imposed on the dignified by the common majority. Both of them, as Nietzsche says, make the world "become a dream." In Antichrist, he diagnoses religion as follows: "neither morality nor religion has any point of contact with actuality. It offers purely imaginary causes ("God", "soul", "ego", "spirit", "free will" - or even "unfree"), and purely imaginary effects ("sin", "salvation", "grace", "punishment", "forgiveness of sins"). Intercourse between imaginary beings ("God", "spirits", "souls"); an imaginary natural history (...); an imaginary psychology' [23]. 
Bearing in mind Freudian metaphor of a dream, there is no doubt that these imaginary elements (after all forming a very coherent system) are parallel to the façade that was a characteristic feature of a dream. Let's recall the second quotation from The Daybreak: 'Dreaming and responsibility. You would wish to be responsible for everything except your dreams! What miserable weakness, what lack of logical courage! Nothing contains more of your own work than your dreams. Nothing belongs to you so much! Substance, form, duration, actor, a spectator in these comedies you act as your complete selves' [20, p. 78].

This passage is really significant - even in dreams the subject is themselves, although it does not necessarily have to be conscious of a system of beliefs and morality that they share to and as well as all the frustrations that result from it. Let's refer to Freud again. The author of Interpretation of Dreams explains it in a very simply way - a dream is a fulfillment of a hidden wish. A dream is a place where we have to do with the real nature of a man, although because of a caesura a dream can take such a twisted form that it becomes brutal and traumatic. As everybody knows, according to Freud both dreams and all forms of similar structure, such as a phobia or a neurosis, including a collective one, that is religion, result from a complex mixture of a drive, a ban and a complex. Despite all that, the content of a dream does express some truth about ourselves.

Nietzsche has no doubt that any consciousness originates in the sphere of the subject that is guided by instinct and drives. According to, among others, Michel Onfray the whole Freudian concept of unconsciousness and impulsivity, including displacement and sublimation, originates in Schopenhauer's notion of "a will to live" and in Nietzsche's philosophy, especially in his theory of "will to power." The categories of will to power, as well as known from the Freudian psychoanalysis notions of displacement and sublimation which also find their origin in the philosophy of the author of Thus Spoke Zarathustra are clearly visible in Nietzsche's reflection on Christianity: "The "Christian" - he who for two thousand years has passed as a Christian - is simply a psychological self-delusion. Closely examined, it appears that, despite all his "faith," he has been ruled only by his instincts - and what instincts! - In all ages - for example, in the case of Luther "faith" has been no more than a cloak, a pretense, a curtain behind which the instincts have played their game - a shrewd blindness to the domination of certain of the instincts...' [23, p. 39]. Passing over a problem of engineering of religion that was discussed by Nietzsche among other things in his Antichrist and On the Genealogy of Morality, the fact that its genesis and its motive is a desire to reevaluate values in such a way that they would subordinate dignified people to the weak ones let's pay attention to what religion is for the believer subject themselves. In On the Genealogy of Morality Nietzsche shows very interestingly what Christianity does to the real determinants underlying it. The basic determinants are situated in a Trieben sphere, that is the sphere of drives. As these determinants are to remain hidden, there are three possible types of psychological shifts: Triebversicht (displacement of a drive), Triebaufschub (adjournment of a drive) and Triebvershiebung (redirection of a drive). The drives certainly do not disappear, they do not become eradicated but they do change the way they are fulfilled. The drives in question which Nietzsche writes about are involved in the will to power that takes different forms, and which is fulfilled in a resentment and indirect way, at the same time remaining a form of aggression and cruelty towards of the strong by the weaker. Here the dream facade is a whole complex of religious beliefs and moral convictions that are related to them - the faith in God, the consecration of Christ as well as eternal life, humility, love of neighbor, rituals, dogma. Their rational, hidden and redirected determinants, however, are just resentment, lust for domination, hatred and revenge.

Even a cursory glance at a depiction of religion in alienation criticism draws attention to a difference between this trend and the one that seems predominant nowadays among the other atheist ones, that is New Atheism which is adopting the post-Darwinian perspective. For Dawkins, Dennett, or Harris, religion is a simple cognitive error that is relatively easy to uncover by indicating its irrational and inconsistent elements as well as natural genesis. A "sharp voice of reason" is completely enough to do it. The alienation trend in turn points out to a much more 
complicated and to some extend "layered" structure of religion - behind a coherent façade (which does not mean the rational one) there are some motives, concealed secretly. They do possess their ratio but it is camouflaged well, disassociated by psychological censorship that is covering up that determinants of religion (alike those of other formations similar in structure to a dream) are neither to the credit of a believer subject nor to engineers of religion (see, for example Marx's concept). However, it does not influence the fact that the façade is a symptom and its interpretation makes it possible to reach the determinants. Thus alienation criticism of religion tries to investigate why the Feuerbachian subject creates a notion of God that humiliates themselves, why the Nietzschean higher man is to be "seduced" by Christianity at the expense of resigning from life here and now, why the Sartrean subject denies themselves freedom in the name of the projection of the oppressive look that is chasing them, why the man according to Žižek resigns from being active and falls back on being alienated by the Big Other. The dream which is dreamt by an alienated subject has an enormous seductive power. That is precisely why in order to solve these puzzles, the alienation criticism of religion must reach into archeology of human consciousness, but assuming an overriding purpose, very close to Hegel's goal - to make the subject cease to be a mystery to themselves.

\section{Unmasking of False Consciousness}

In accordance with the thesis I am proposing in this article, we can speak of a certain soteriological ideal within the alienation criticism of religion, the one which is realized by this trend by the unmasking of false consciousness. Next step involves the creation of a project of a new subject: full, real and capable of transgression. This project is not fully developed and its realization can be implemented in a couple of directions: both towards moral heroism and towards focusing the subject on themselves their own. Alienation criticism of religion does not say exactly what the "content" of a new subject is like (clear values, ways of acting, etc.). It rather focuses on a "formal" procedure of its construction. The context of which soteriological threads of this trend constitute is an affirmation of the truth proclaimed by it.

The conviction of a salvific role of the truth is one of the aspects that almost all atheistic philosophers have in common. One should bear in mind that it is not happiness, prosperity or peace that do save the subject. First and foremost, it is the truth that does it, even if that difficult to accept. Even if religion brings benefits to the subject - it acts as an escapist function, organizes social life, etc. - the subject pays far too much for that. A characteristic feature of all philosophical trends focusing on criticism of religion is Prometheanism. The trends aim to liberate a man from religious superstition and to direct him towards the truth. At the same time alienation trend emphasizes the existential truth, the truth of the subject as religious alienation is a fundamental self-imposture which should be disenchanted. Only the subject that exists authentically and is not contradictory in themselves, self-controllable and aware of one's own capabilities, can be saved. Obviously, in a secular sense. An ideal of existential truth as the main postulate of alienation criticism of religion is already present in Feuerbach's works, but it plays a vital role in Nietzsche's thought to which subsequently Freud refers. The ideal is later developed by the successive representatives of the trend. In the Marxist tradition, in turn, the existential truth is associated with the proclamation of the unity of thought and action which in the alienation criticism of religion enable a real transformation of the one and only reality available - the reality here and now. At the same time it is worth noticing that according to the thinkers in question, the secular salvation is required not only by an individual subject but also all of their contemporary culture. A problem of the truth is also debatable here - the truth that culture is devoid of. Surprisingly, it is Feuerbach who already draws attention to the same thing that nowadays is being diagnosed by Lasch, Bell, Bloom, and Baudrillard: culture is being trivialized, subjects that constitute the culture are endangered by narcissism, routine, cynicism, automatism. There is probably one and only remedy for this situation: the transformation 
of existence, recovery of autonomy and in the first place, a sense of efficiency. These threads are found in works by all representatives of the trend. They all associate trivialization and cynicism that are so characteristic for Western culture with supporting of a routine and an inauthentic form of human functioning. The first step which should be taken in order to change this situation is the unmasking of false consciousness. The second one would be a project of a new subject.

The unmasking of false consciousness consists primarily in unveiling a mechanism of alienation. Basically, all the representatives of the trend in question refer to the Feuerbachian scheme: we deal with self-imposture, projection, and lack of recognition of our own essential aspects of being as ours. The differences between them appear among other things once a question about a cause of alienation is asked. In The Essence of Christianity by Ludwig Feuerbach where one comes across a complete schema of religious alienation applied in a context of atheistic philosophy for the first time, they do not find a satisfactory answer to this question. In the later Lectures on the Essence of Religion, the author suggests a sense of dependence on nature as one of the reasons of alienation. However, it is not in line with the thesis presented in his previous (and undoubtedly more influential) work and causes a considerable dissonance between The Essence of Christianity and Lectures. Marx is the one who polemizes with this resolution. Having adopted the Feuerbachian schema of alienation from The Essence of Christianity he claims at the same time that it is not possible to understand the genesis of religious alienation without a reference to a political context. Religious alienation is one of manifestations of more broadly understood social alienation which in turn is caused by a political-social system that has been wrongly structuralized. In this case the origin of religion is reduced to two sources: on the one hand, in an imaginary and distorted way it reflects the prevailing and unjust social system; on the other hand, it supports it deliberately. It becomes "the opium," which promises to replace the passive suffering and injustice of the subject with a reward after their death. The cause of religious alienation is therefore social injustice, manipulation, and suffering of the individual.

Nietzsche and Freud notice the origin of religious alienation in repression of drives. The theories of both thinkers were often compared with each other even during Freud's life, although he strongly denied not only being inspired by Nietzsche's thought, but also the knowledge of Nietzsche's works. However, commentators draw attention to Freud's strong dependence on Nietzsche's thought which can be seen in his central depiction of drives as well as in the construction of a concept of unconsciousness, sublimation or repression of the drives. Even though, while comparing these thinkers it is impossible to forget about such differing components of shaping religious attitudes as Oedipus complex in Freud's thought or rebellion of slaves in Nietzsche's works, the psychology of the subject completing self-alienation in religion is outlined by both of them in a similar way. Nietzsche and Freud consider it always in a context of three factors: a relation of a man to themselves, the activity of their drives and a manner in which these drives are converted. For Nietzsche, the key word here is "resentment," for Freud it is "a complex." In both cases, an important role in the construction of religious beliefs is played by a motive of repressed and camouflaged revenge.

The categories that were later adopted by Freudian psychoanalysis began to appear in Nietzsche's thought in the late 1970s in a work Human All too Human (1878), in which he mentions sublimation in a psychological sense for the first time. In Beyond Good and Evil (1886) Nietzsche emphasizes a sexual drive that is displaced or transformed in religion and like Freud he compares religion itself to neurosis. However, the most interesting works are those from the late 80's relating precisely to religion: On the Genealogy of Morality and Antichrist, within which a notion of "resentment" becomes the key word. Nietzsche does not provide a precise definition of resentment, pausing at such depictions as "spiritual self-intoxication", "telling oneself lies," "targeting at the outside," but following Max Scheler we can accept understanding of resentment as a constant mental attitude that arises when emotional reflexes and passions are systematically repressed [34]. These reflexes and passions involve: a reflex of revenge, hatred, malice, jealousy, 
etc. The repression is closely connected with the disintegration of the subject, their self-alienation and appearance of pathological symptoms. An intersubjective effect of this phenomena, however, is the emergence of a new, re-evaluated system of values and religion. A similar mechanism is described by Freud in Totem and Taboo. Skipping the aspect of totemic feast and focusing on the psychology of an individual subject - the source of religion is the transformation of a drive and covering the tracks of a primal motivation. For both Nietzsche and Freud, this genesis is connected with such psychological mechanisms as displacement and compensation in the world of illusion. Nevertheless, Freud elaborates on this theory associating it with a father's complex whereas Nietzsche presents religion as a tool of revenge that is performed by the miserable on the dignified.

In Sartre's opinion, religious alienation is a form of escape from responsibility. French philosopher equips the subject with freedom of conferring a sense which turns out to be a burden. Trying to reduce unavoidably related fear, the subject is likely to escape into routine actions and colloquial or daily morality. All these ways involve negating one's own transcendence, perceiving oneself as a thing of established nature and sense. Religion is just one form of such an escape. The aspect of absolute freedom that the subject is equipped with is shown in the project outside and attributed to an illusory being. This very being is at the same time a response to the longing of the subject for a certain ontological whole: the synthesis of being in itself and being for itself.

Apart from differences, a general diagnosis - alienation of a subject resulting in an inauthentic existence - is the same for all the representatives of the trend. They also ask a question whether unveiling the subject involved in religion in front of the consciousness will result in liberation. The answer is rather negative. Feuerbach represented a very optimistic attitude and in his opinion "disenchanting" of the false consciousness would be an effect of appropriate education. At the beginning of his work Marx used to agree with such reasoning, however, later he proposed a more sensible thesis: a change of the most important aspects of consciousness is impossible without a change of social conditions. Marx's gloomy continuator (and a mocker at the same time) is Žižek who claims that a dominant attitude in our society is a cynical one. Even if the subject does not believe "spiritually," the subject participates in a religious paradigm, supports it with their own practice, and still remains alienated due to a fundamental dissonance between a thought and an action. Despite these sad conclusions, alienation critics of religion do not resign from their faith in a possibility of secular salvation of the contemporary subject. They believe that authenticity, working activity, true and active secular faith instead of cynical inertia is possible and should be pursued. A trial to construct a new subject will be shown at the example of a thought by Friedrich Nietzsche, one of the most influential representatives of alienation criticism of religion.

\section{Salutary Meaning of Sublimation}

The term that often runs through this article to designate a man facing alienation is an epithet "authentic." Although it is quite a problematic word because of its historical background, in fact, there is not a better one. Without going into historical details of this notion, one should remark that it has been related for a long time with a discovery of an inner self which is much more intimate and real in relation to what is presented by the subject outside. One can find it used in such a sense in works by Hölderlin or by Rousseau who is said to have propagated the notion. "Discovering one's self" has become a slogan and is used unusually often in our culture in different contexts, both serious and pop cultural ones. However, significantly it has nothing in common with a concept of a new man who is proclaimed as a soteriological ideal of alienation criticism of religion. First of all, alienation trend suggests an anti-substantial understanding of the notion of authenticity - a new man is the one who dissociates from expressions that would captivate him, creates himself without relying on any "ready" and "existing" self. One of the sources of such a depiction of a new man is Nietzsche's anthropology. 
Friedrich Nietzsche's thought is a real breakthrough in a tradition of understanding the term authenticity. His aphorisms are so ambiguous that he can be recognized as both: a critic and an eulogist of this idea. However, he sounds critical only when he negates the concept of inner self that can be discovered and know. "True, inner self" - he writes in Untimely Meditation - it is a fantasy or "mythology." Nevertheless, we can try to "look inside ourselves." What will we find there? Nothing except a bundle of antagonistic drives. Originally the subject is scattered and multiple. Yes, it is capable of achieving their inner coherence - as Nietzsche writes in On the Genealogy of Morals - in a resentment and twisted manner that additionally conceals assiduously their own motivation. At the same time, he suggests that there may be another, more recommendable way of dealing with the bundle of drives that constitute us. Nietzsche speaks of a true way of being. It is also based on a certain project but the project which is proper and desired. It is evident that a serious shift in understanding of a notion "authenticity" is a characteristic feature of Nietzsche's thought if it is analyzed in a perspective of the history of ideas. The term no longer designates fidelity to the uncovered inner core of personality but is realized in a project whose implementation is determined by a certain procedure. In Joyful Wisdom, Nietzsche proclaims that basically a man is assigned to enrich their style, add some autonomy and creativity to their character as these features are distinguishing for humanity. However, let's not forget that according to Nietzsche a man is a reservoir of contradictory drives. The statement makes him explicate a basic condition that constitutes a new man: the continuous overcoming of oneself.

Presented by Nietzsche existential ideal is to be complemented by a modern man. Similarly to the rest of the representatives of alienation criticism of religion, he also draws attention to fundamental complaints of his time, a fact that a man has fallen into conformism, automatism, routine, banality and negation of anything that possess value. The only alternative to this phenomena is the realization of an existential project based on a crucial role of transgression - the transgression that is necessary if we do not want to become slaves to our disruptive and contradictory drives. Nietzsche uses one of his key words to describe it: Überwindung - selfovercoming.

Nevertheless, the concept of Überwindung in Nietzsche's works is ambiguous and generates some problems with its understanding. Let's ask a basic question: what is actually being overcome and how? The notion of self-overcoming gains its meaning in the later Nietzsche's works, from the 80s. At that time, he does not write about numerous autonomous drives any longer and brings them all together as a will to power. The case is quite controversial, as evidenced by a discussion between Walter Kaufmann and Giles Deleuze. These commentators argue quite sharply about the relationship between the forces that are being overcome. According to Kaufmann Nietzsche in his early works inclines to a statement that contradictory principles are strength and reason. On the other hand, within a developed stage of his philosophy, which is the main point of reference for us, Nietzsche turns to an attitude classified by Kaufmann as monism. The factor that is to overcome and is being overcome at the same time is solely the will to power manifesting itself in numerous ways. At the same time Nietzsche rejects the sovereignty of reason that is also reduced to the will of power. Despite all that, a man is not its play. Although it constitutes the metaphysical principle of reality, it does not exclude human activity and autonomy. That is why Nietzsche, in spite of all, values reason and intellect more than, for example, the realization of a sexual drive that can cause captivating of the subject. Moreover, Kaufmann claims that only being reasonable can guarantee a man power of self - determination and self-control.

The preceding description comes down to the fact that Kaufmann ultimately classifies Nietzsche as a "dialectical monist." In his depiction self-overcoming of the will to power leads to a synthesis of its aspects. In conclusion, Kaufmann notices a clear parallel between the Nietzschean Überwindung and the Hegelian Aufhebung. In turn, Deleuze sees Nietzsche in a different way. He is convinced that Nietzsche's philosophy is clearly anti-dialectical in its character. It is not so much dialectical as pluralistic. Deleuze argues that in a situation when we have to do with human 
transgression, the ratio of the overcoming power to the one that is being overcome is never understood as a negative element. In a relation between two forces, the one which imposes obedience negates neither the other one nor anything that constitutes itself. It just affirms the difference and enjoys it.

Once we try to apply psychological categories in place of the Hegelian terms, the difference between Kaufmann and Deleuze might appear less serious. It is clear that transgression which is crucial for a creative human being consists in overcoming some manifestations of the will to power by means of the other ones. However, there is a question whether the transgression is a continuous struggle that is just fated to failure? Does it come to an end? Does human creativity possess a better or worse form? When can we say a man "possess themselves" and when that they are "divested of themselves"?

A distinction between repression and sublimation that occurs in Nietzsche's late philosophy presents this problem in a slightly different light. As it was mentioned before, religious behaviors are primarily related to a mechanism of repression - a man denies all that is fundamental for them (although displaced elements do come back), at the same time alienating themselves. Similarly to Freud, Nietzsche was never a supporter of an immediate, debauched realization of all the drives. Despite some liking for "blond beasts," the ideal affirmed by Nietzsche is a self-controlled man that is capable of overcoming themselves. Nevertheless, it is not so easy while a man is defined as a reservoir of contradictory drives.

The problem of the distinction between repression and sublimation sets us on an appropriate trail of understanding a soteriological ideal of existence. Whereas repression generates "unreal" existence, sublimation is the one and only proper way of dealing with one's own impulsive nature, which, as it was mentioned before, always expresses the will to power. As Kaufmann notes, the process of sublimation in Nietzsche's philosophy has been either disregarded or omitted for a long time [17]. Even in such a "psychologizing" work as Jasper's study of Nietzsche, sublimation is only mentioned as one of the numerous ways to "cope" with a drive and the author neither emphasizes it nor attributes any special role to it.

In fact, the term sublimation understood according to in Nietzsche's late thought belongs to key words and is closely related to an ideal of self-overcoming as one of the soteriological threads. Not only does Nietzsche anticipate Freud in this case, but also is a figure who for the first time in the history of ideas formulates a psychological meaning of the word sublimation.

In Human, All too Human he defines sublimation in a way that is close to Freudian interpretation and the approach of later psychoanalysis. Sublimation, as he writes, consists of a process within which "what is rational" comes into being from "the irrational," "logicalness" from "illogicalness" and "impartial" from "greed." However, the problem of distinguishing between repression which results in an inauthentic existence and sublimation that plays a key role in forming a creative and unalienated existence is quite difficult. As an example, one can have a closer look at Christian love of neighbor. As Nietzsche points out, it is an effect of resentment and in fact, it is nothing else but a veiled vengeance. Briefly put, it results from repression, not sublimation. Nevertheless, it does not change the fact that the "social effect" itself is positive. Why cannot we just say that simply a sublimation of negative drive has taken place? After all, "impartiality" has emerged from "greed." Certainly, one can remark immediately that in a broader perspective of the Nietzschean theory of religion and the revaluation of values in order to subordinate "the strong" to "the weak" it is actually apparent. Still, the question of Christian love of a neighbor shows how subtle and at the same time significant distinction we are to deal with when it comes to repression and sublimation. This problem becomes even more evident when Nietzsche's reflections on Freud's theory are confronted. Ken Gemes in his article Freud und Nietzsche on Sublimation shows relations and differences between them and proves that contrary to all appearances, the opposition of repression and sublimation is clearer and much more consistent in Nietzsche's thought that preceded Freudian psychoanalysis [12]. 
To begin with, let's recall Freud's distinction between repression and sublimation, bearing in mind that like Nietzsche he took the view that sublimation of a drive determines a healthy subject. Suppression of drive results in "restitution of the displaced" in the form of pathological symptoms which are some sort of "substitute" of a direct target on which the displaced drive is directed. Sublimation prevents from uncontrolled "restitution of the displaced" and at the same time its effects are also "substitutes." However, the thing is whether there is any reliable criterion that clearly distinguishes these substitutes from the symptoms connected with the restitution of the displaced. According to Gemes, Freud's solution is not entirely satisfactory because in order to distinguish between these two types of psychic formations he had to refer to arguments beyond a discourse of psychoanalysis. It is evident within a comparison of two cases that he analyzed: Leonardo da Vinci's and Daniel Paul Schreber's.

Leonardo da Vinci, a Memory of his Childhood (1910) is one of the most important Freudian studies devoted to a problem of sublimation. Just at the beginning, Freud distinguishes three ways of dealing with a sexual drive in childhood that ultimately determine what type of person the subject will become in their adulthood. The first manner encompasses displacement of a drive into unconsciousness along with the reduction of a desire to achieve knowledge (lack of interest in sex, also within a sphere of ratio, that is questions addressed to parents, etc.). The second one also includes displacement of a drive into unconsciousness but this time the drive returns within a sphere of knowledge. Finally, the third way is connected with sublimation and characterizes people who transform a drive into a craving for knowledge which strengthens a strong research drive. For Freud an example of this third type of man is Leonardo da Vinci, a man who sublimated his own sexual drives into artistic and research activities at the same time - he presumes - remaining an ascetic in his sexual life. Interestingly, Da Vinci himself is either portrayed by Freud once as a genius of sublimation or as an "obsessive neurotic" fixed at an infantile phase of his own development. Freud devotes a lot of attention to Da Vinci's relationship to his mother and father that he finds and presents as extremely problematic. Nevertheless, Leonardo's first depiction prevails: he avoids repression and the effects are well-known in a form of fantastic works of art and intriguing research sketches.

An analysis of a case of repression, presented in a certain sense as an antithesis of Leonard's attitude, can be found within reading another of Freudian sketches: Psycho-Analytic Notes upon an Autobiographical Account of a Case of Paranoia (Dementia Paranoides) (1911). Like in a study of Leonardo its author analyzes a case of a person he did not examine personally: this time it is the former president of the Saxon Senate, Daniel Paul Schreber [35]. As analysis material, Freud used Schreber's autobiography. Its author survived a three-times episode of mental illness, two of which were described in details in his book (the third one is known only from hospital documentation). In a case of the second episode that was treated in a closed psychiatric hospital, among other things we have an access to a brief description of an illness prepared by the court to whom Schreber applied for a release from the institution. In this document, his character is recognized to be aspiring to save the whole world and to restore a state of lost bliss. The mission is likely to succeed only if the character in question transforms himself into a woman. The condition was finally qualified as a manic formation.

Freud analyzes this case in much the same way as Leonard's case but classifying its cause as a classic form of repression of a drive. Devoting a lot of attention to an analysis of Schreber's relationship with his father and his physician Dr. Flechsig who used to treat the first of the sickness episodes Freud concludes that the cause of Schreber's problems was - like in Leonardo's case unaccepted homosexual impulses. As far as Leonardo is concerned, Freud comes to this conclusion mainly by analyzing his works in which he sees idealized figures of men or women of an androgynous appearance. In Schreber's case among other things, he focuses on dreams within which the man fantasizes about becoming a woman fulfilling her matrimonial duties as well as on the content of manic fantasy in which similar images appear but this time gaining a religious 
context. In both cases, we are to deal with a homosexual impulse. The difference lies in a way it is transformed: Leonardo sublimates his drive in a creative activity, Schreber falls into a religious mania.

A key question that should be asked at this point is about an exact difference between these two cases? As Freud proves we are never able to avoid any form of displacement of a drive but we can transform it in a different way in the long run. Actually, why are we to assume that Schreber with his religious obsession is less healthy than Leonardo obsessed with making sketches of flying machines and other never-completed projects? Is the difference between sublimation and repression really the one of an antagonistic character?

Ken Gemes claims that a fundamental problem in this distinction is that following Freud, we would ultimately have to end up explaining the results of sublimation emphasizing their social value. Affirming Leonardo's character, Freud speaks of "high cultural accomplishments," "redirecting of a sexual drive towards higher goals" such as science or art. This means introducing non-psychoanalytic and valuing terms into the definition of sublimation. In other words, the same behavior can be once classified as pathological and another time as sublimated one [9]. That is also the reason why the characters of Leonardo and Schreber were evaluated by Freud in a completely different way. According to Freud obsessive behavior and thinking focused on God do not have any social value whereas the works created by Leonardo do have.

At this point, it is worth going back to the very sources - that is to Friedrich Nietzsche who is a bit clearer about the issue. In his view, the distinction between repression and sublimation is not a measure of "health" or "sickness" but a difference between a weak and resentful subject and a strong one that is capable of auto-creation. Both of them face an internal conflict between drives that cause them to experience internal "uproar" and "struggle." The measure of the power of the subject will be an ability to overcome this sensation. A sublimating subject will primarily be the one that transgresses themselves (overcomes themselves) and the one that "exists in a real way" in a sense of their capacity of full self-control.

According to Gemes a notion of "splitting off" which is used in the first place in reference to repression is at the same time the one that helps to understand the Nietzschean distinction between repression and sublimation. On the one hand, the term signifies a separation of a right impulse from consciousness. On the other hand, it means a total separation of an impulse and its proper realization. The "splitting off" can be also treated as a measure of a subject alienation - the subject separates themselves from their own motives which, as psychoanalysis points out, do not disappear but just slip out from their domination. Nietzsche - like Freud in his study of Leonardo - is convinced that the problem of "splitting off" affects both the weak and the strong. However, while the weak one surrenders to resentment, the strong one is capable of struggling with themselves and is able to redirect their drives towards a higher goal. It is also significant that in an act of sublimation redirected drives are put to appropriate use entirely, which means that traces of their possible displacement will not return in an uncontrolled form but totally surrender to a domination of the subject. While in a case of repression a man becomes a "slave" of their own drives, in sublimation from the beginning to the end they do serve them. It is also important that - in Nietzsche's view - in sublimation process, there is no falsification of a primal drive or its complete transformation into the opposite one. The drive is subordinated to the subject and transformed. Although it cannot be realized in a direct and uncontrolled form, it still retains its authentic character. It seems obvious once we refer to an opposite case of Christian love of the neighbor. According to Nietzsche it "grows out of a trunk of hatred" and what is also worth mentioning it never recognizes its true motives. A Freudian opposition between the cases of Leonardo and Schreber could be recalled again and one should make an attempt to interpret the contrast in question in a Nietzschean manner, certainly bearing in mind the hypothesis put forward by Freud. In Leonardo's case the homosexual drive "has got refined" as a result of subordination to scientific research and artistic activity but at the same time, it has not lost its chance of adequate expression. 
Hence his concentration on a study of a human body and imitating male beauty in pictures of men and androgynous women. Da Vinci is entirely in control of himself subordinating all his impulses to what he perceives as superior: a drive to a scientific and artistic creativity at the same time incorporating his own sexual drive in the activity. Therefore, if we analyze Leonardo's case from a Nietzsche's point of view a factor that evaluates his attitude is not social value of his works as it is suggested by Freud but an ability to control himself while simultaneously integrating the drives and subjugating them. On the other hand, as far as Schreber is concerned, we have to do with psychological disintegration and the opposite of a full, unified "I" that could be noticed in Leonardo's case. Displaced homosexual impulses explode here at different stages of religious mania which is entirely beyond his control and which turns out to be a completely inadequate form in relation to its primal motives. Besides, it is worth noticing that apart from the episodes of mania, Schreber presents himself as a rational, skeptical of religion and responsible politician as well as a staid spouse. In the Nietzschean psychology of drives, as Gemes points out, sublimation means that stronger drives integrate the weaker ones which enables these weaker to express. On the other hand, repression noticed in Schreber's case consists in a fact that stronger drives try to suppress the weaker to such an extent that their expression is sometimes restrained completely. Still, it more often reveals in a strongly distorted form, usually aimed at the opposite of the original. This is exactly what in Nietzsche's opinion happens in case of Christianity: hate, jealousy or a desire for domination present themselves in a form of fraternal love.

Although Nietzsche's theory is not as thoroughly prepared as Freud's concept it does hold an advantage over it. As opposed to Freud, distinguishing between repression and sublimation it remains strictly within the internal life of the subject without resorting to any external criteria. The social value of deeds does not decide whether the subject is "healthy" or "sick." It is determined by their own relation to themselves and a degree self-control. The difference between a subject who victimize their drives and the one that sublimates them is ultimately reduced to a degree of internal, mental integration and self-control. A figure of self-control has a great significance for Nietzsche and is crucial in his creation of existential ideal. Its actual meaning is revealed only when we understand thoroughly the difference between repression and sublimation. This difference reveals an outstanding feature in the psychology of alienated man as well as the psychology of man from alienation. At the same time it refers to a notion of transgression whose comprehension is also determined by a proper understanding of sublimation. An analysis of a concept of sublimation in Freud and Nietzsche's works reveals two distinct components of a soteriological existential ideal: on the one hand there is "I" that has been liberated from alienation, more unified, restored to themselves and complete; on the other hand there is a self-controlled and able to transgress one. The notion of transgression itself is not characterized by an uncompromising struggle or pluralistic coexistence of Deleuze's pluralism. If we have a closer look at self-transgression taking place within the subject from a perspective of the Nietzschean concept of sublimation, we realize the necessity to cope with integration that is simultaneously related to precise self-control.

Finally, let's refer to a concept of an excess of life and passion that is related to it. A proper form of existence suggested by Nietzsche associates with vitality, self-control, and enigmatic figure of "passion" understood not just as a blind drive but as a figure organizing the rest of drives. According to Kaufmann, this figure is equal to the firmly affirmed by Nietzsche pure reason. In my opinion, it is not so obvious. Gemes writes about "a dominant drive." What is this "dominant drive"? Nietzsche does not answer this question explicitly, restricting himself to pointing out the only measure that defines it - absolute commitment to the impulse chosen as prevailing - the mentioned before - "passion." 


\section{Conclusion}

The model of an authentic subject presented by Nietzsche presents explicitly the main elements of a soteriological existential ideal created by alienation criticism of religion. Its starting point is an alienated subject that is internally "divided," unaware of the truth about themselves and consequently unable to control themselves. An answer to this problem, shared totally or partly by the other representatives of the trend, seems to be the subject found within Nietzsche's concept. It is autonomous, autocratic and creating oneself in the truth. On the other hand, an analysis of Nietzsche's theory points out some inevitable problems associated with understanding the subject in such a way. We have to do with the one that has liberated themselves from an alienating projection of God. However, who is the subject now? The same one as "before" alienation or maybe someone completely different? Alienation critics of religion know that the return to a hypothetical prealienation state is impossible. Instead, they emphasize an element of creation. After getting rid of dependence on an idea of God, a man is capable of being exactly the one that they have created themselves. Nietzsche's philosophy suggests that defining a path to existential salvation of the human being understood in such a way comes down to a certain procedure: you can become whatever you want to be like. However, the manner of self-construction is not arbitrary. In this case, Nietzsche speaks of consistency, active organization of our contradictions and creative applying a style to our character in harmony with principles that we find the most important. Nevertheless, the problem of choosing the principles according to which we are to accomplish our auto-creation does reveal basic antinomy of the soteriological ideal proposed by alienation criticism of religion: the problem is to what extent the choice in question is identical with our will or our desire? Where is a boundary between existential freedom and total arbitrariness? These are the questions that the alienation criticism of religion is still trying to find answers for, opting for a practical aspect. Which of our choices can be described as authentic is ultimately determined by a degree of our involvement in it and by our awareness of responsibility. The representatives of the alienation trend more and more often write about a necessity of real, secular faith whose verification would be an explicit proclamation and in the first place acting in accordance with it. Conclusively, our authenticity can only be proved by our practice.

\section{References}

1. Assoun, P. Freud and Nietzsche, London: Continuum, 2000.

2. Feuerbach, L. Das Wesen des Christentums, In L. Feuerbach, Gessamelte Werke, W. Schuffenhauer (ed.), Berlin: Akademie Verlag, 2006.

4. Freud, S. The Interpretation of Dream, Transl. by J. Strachey, New York: Basic Books, 2010.

6. Freud, S. Totem and Taboo. Some Points of Agreement between the Mental Lives of Savages and Neurotics, Transl. by J. Strachey, London: Routledge, 2001.

8. Freud, S. The Standard Edition of the Complete Psychological Works of Sigmund Freud. 24 vols, Transl. and ed. By J. Strachey, London: Hogarth Press, 1961.

9. Gardner, S. Irrationality and the Philosophy of the Psychoanalysis, Cambridge: Harvard University Press, 1971.

10. Gay, V. Freud on Sublimation - Reconsiderations, Albany: State University of New York Press, 1992.

11. Gemes, K. Freud und Nietzsche on Sublimation, The Journal of Nietzsche Studies, 38, 2009, pp. 38-59.

13. Gemes, K. Nietzsche on the Sovereign Individual, Free Will, and Autonomy, Aristotelian Society (Suppl.), 80 (2006), pp. 321-39.

14. Golomb, J. Nietzsche's Enticing Psychology of Power, Jerusalem: Magnes Press, Hebrew University, 1989. 
15. Groddeck, G. The Book of the It, New York: Vintage Press, 2006.

16. Hacker, F. Sublimation Revisited, International Journal of Psycho-analysis 53 (1972), pp. 21923

17. Hegel, G.W.F. Phänomenologie des Geistes, Berlin: Duncker und Humblot, 1841.

18. Heidegger, M. Nietzsche, vol. 1: The Will to Power as Art, Transl. by D. F. Krell, New York: Harper and Row, 1979.

19. Jaspers, K. Nietzsche, An Introduction to the Understanding of His Philosophical Activity, Cambridge: Johns Hopkins University Press, 1997.

20. Kaufmann, W. Nietzsche: Philosopher, Psychologist, Antichrist, Princeton and Oxford: Princeton University Press, 2013.

21. Lehrer, R. Nietzsche's Presence in Freud's Life and Thought, Albany: State University of New York Press, 1995.

22. Marx K. Critique of Hegel's 'Philosophy of Right,' Transl. by A. Jolin \& J. O'Malley, Cambridge: Cambridge University Press, 1982.

23. Nietzsche, F. Daybreak. Thoughts on the Prejustice of Morality, Transl. by J. Hollingale, Cambridge, Cambridge University Press, 2006.

25. Nietzsche, F. Human, All Too Human, Transl. by G. Handwerk, Stanford: Stanford University Press, 1997.

26. Nietzsche, F. On the Genealogy of Morals, Transl. by D. Smith, Oxford: Oxford University Press, 1996.

27. Nietzsche, F. The Antichrist, Transl. by A. Knopf, Białobrzegi: Masterlab, 2014.

28. Nietzsche, F. The Gay Science, Transl. by J. Nauckhoff \& A. Del Caro A., Cambridge: Cambridge University Press, 2001.

29. Nietzsche, F. Thus Spoke Zarathustra, Transl. by A. Del Caro A., Cambridge: Cambridge University Press, 2006.

30. Reginster, B. Nietzsche on Ressentiment and Valuation, Philosophy and Phenomenological Research 57 (1997), pp. 281-305.

31. Ricoeur, P. Freud and Philosophy: An Essay on Interpretation, Transl. by D. Savage, New Haven: Yale University, 1970.

32. Schacht, R. Nietzsche, London: Routledge and Kegan Paul, 1983.

33. Scheler, M. Ressentiment, Transl. by W. W. Holdheim, New York: Schocken, 1972.

34. Schreber, D.P. Memoirs of My Nervous Illness. New York Review of Books: New York, 2000.

35. Segal, H. Dream, Phantasy, and Art, London: Routledge, 1991.

36. Žižek, S. The Plague of Fantasies, London: Verso, 1997.

37. Žižek, S. The Sublime Object of Ideology, London: Verso, 1989.

\section{Notes}

1. The article was written as part of "Sonata" grant no 2013/09/D/HS1/00348 by Narodowe Centrum Nauki. 